ORCID: 0000-0003-1308-8235

Uniwersytet Łódzki

magdalena.henczel@uni.lodz.pl

\title{
Baśniowe przestrzenie działania z perspektywy przyszlych nauczycieli
}

\section{Summary}

Fairy-tale places of action from the perspective of future teachers

The aim of the article is to present meanings associated with fairy tale places by teacher candidates. The research data came from interviews with 57 early childhood pedagogy students, analysed through a qualitative method. The competences of candidates for teachers in perceiving the symbolism of places, wandering, world layout, reveal not only the level of cultural and literary knowledge (because they are a "showcase" of previous school experiences of fairy-tale themed lessons), but also indicate their future strategies for designing children's activity based on fairy tales. These strategies may turn out to be so durable and resistant to change that they might survive university literary education and remain the starting point for students' teaching practice. The research shows that the fairy tale can remain in them as the starting point for fun or a "background" for science, mathematics and language.

Keywords: students' reception of fairy tales, strategies for using fairy tales in early childhood education, candidates for teachers

Słowa kluczowe: recepcja baśni przez studentów, strategie wykorzystania baśni w edukacji wczesnoszkolnej, kandydaci na nauczycieli

\section{Wstęp}

Baśń, widziana jako „elementarz napisany w języku obrazów. (...) języku, dzięki któremu możemy rozumieć siebie i innych" (Bettelheim 1985: 40), stanowi bijące źródło odkrywania sensu literatury. Przestrzeń baśni pozwala „wytyczyć przestrzeń nadziei, zrozumieć sens doświadczeń i nadawać kierunek biegowi zdarzeń, przede wszystkim zbudować wyobrażenie życia, linii losu i horyzontu doświadczeń" (Leszczyński 2006: 62). Taki sposób rozumienia wydaje się być przykryty dyskursem uobecnionym w przestrzeni społeczno-kulturowej i edukacyjnej przez: 1) popularyzowanie, przede wszystkim w tworzywie filmowym, postmodernistycznej gatunkowej gry, w którą mają zagrać głównie dorośli (np. w serialu Once Upon a Time przestrzenie baśni splątują się z realnymi miejscami świata XXI w., pomiędzy którymi „migrują” znani z opowieści dzieciństwa bohaterowie, 
mający zresztą podobne do współczesnych ludzi rozterki, motywacje i status. Nikt nie jest tu jednoznacznie dobry lub zły, cechą tej gry jest aksjologiczna niepewność. Podobnie jak w Maleficent, gdzie czarownica okazuje się mieć tragiczną historię, uzasadniającą jej rys psychologiczny); 2) wszechobecność zinfantylizowanych i zdeformowanych treściowo wydań baśni (zubożonych w dodatku o wątpliwej jakości ilustracje), która wkracza w świat dziecka przez środowisko rodzinne jeszcze na etapie przedszkolnym; 3) nierefleksyjne pośredniczenie szkoły między tekstem literackim a dzieckiem. Odbiór baśni jako zapośredniczony zawsze zależy od kultury czytelniczej, krytycznego myślenia i wrażliwości nauczyciela. Jeżeli owych kompetencji brakuje - przestrzeń baśni ukorzenia się w realiach Dyskursu Słodkiego Elfa lub Dyskursu Systemu z Deficytami (Klus-Stańska 2007). Nauczyciele budują zatem sytuacje beztroskiej zabawy, odmawiając dzieciom kompetencji poznania „prawd życia” lub za sprawą baśniowych historii dyscyplinują odbiorców tekstu, by ich zachowanie wpisywało się w ogólnie przyjęty społeczny porządek. Z obecnością baśni w przestrzeni szkoły wiąże się szerokie pole nadużyć, presji symbolicznej - choćby w wyniku podporządkowania interpretacji tekstu określonej ideologii (Wasilewska 2012).

Tendencje te narastają lawinowo, tworząc krąg znaczeń, w którym wyraźnym problemem staje się umiejętność niespiesznej interpretacji i symbolicznego odczytywania tekstów (Janus-Sitarz 2013). Istnieje zatem potrzeba rozpoznania „baśniowego” dyskursu przyszłych nauczycieli: zanurzonych w popkulturze, posiadających - przynajmniej teoretycznie - kompetencje do odczytywania tekstów literackich, latami doświadczających edukacji transmisyjnej, a jednocześnie mających pewne wyobrażenie o przyszłej pracy dydaktyczno-wychowawczej. Studenckie widzenie baśni stanowi bowiem jeden z elementów jej aktualnej kondycji w przestrzeni edukacji. Wyjście poza sam etap nadawania znaczeń i podjęcie namysłu nad projektowaniem potencjalnych aktywności dziecięcych wiążą się zaś ze sposobem postrzegania tekstu, który - w wypadku edukacji polonistycznej - powinien być rozpatrywany jako dzieło sztuki literackiej.

W myśl tych rozważań konieczne jest przywołanie koncepcji Lwa Wygotskiego (1980), według którego tekst dzieła sztuki jawi się jako swego rodzaju program zachowań dla odbiorcy; program ten wyznacza określony model świata, w jakim ma zostać zrealizowany. Ów program dany jest wprost w tekście, wymaga jednak kompetencji literackich odbiorcy - ucznia, a nade wszystko - nauczyciela. W kontekście baśni może się to wydawać szczególnie ważne, bowiem na istotę tekstu literackiego ,promieniują” nie tylko „nadane” jej, niekwestionowane przez środowisko szkolne znaczenia edukacyjne, ale też te kreowane przez popkulturę czy tendencję do ujmowania tekstu literackiego głównie jako punktu wyjścia do dziecięcych zabaw (Żuchowska 1998). Nauczyciel powinien posiadać zatem umiejętność odczytywania znaczeń, by móc tworzyć drogowskazy, pozwalające dzieciom na przemierzenie poszczególnych etapów baśniowej wędrówki, która sama w sobie ,stanowi jeden z najbardziej uniwersalnych symboli, mówiący o transformacji bohaterów niezliczonych opowieści (...) przemierzających światy, to zbliżając się, to oddalając od celu podróży, jakim jest spełnienie własnego człowieczeństwa" (Wais 2007: 61). Zasadne wydaje się tutaj przywołanie założeń opracowywania utworów prozator- 
skich na etapie wczesnej edukacji literackiej, w którym akcent padać powinien nie na konkretną wiedzę teoretyczno-literacką, lecz na poszerzanie obszaru obserwacji i refleksji (Żuchowska 1992).

\section{O badaniu}

Pierwotny projekt badawczy zakładał skonfrontowanie dwóch światów: dziecięcego i dorosłego. Wkraczanie w dziecięcy dyskurs przestrzeni baśni miało się dokonać za pośrednictwem zajęć edukacyjnych przeprowadzonych w ramach obserwacji uczestniczącej w czterech klasach II i III. Poprzez wybrane teksty baśni pragnęłam uruchomić myślenie i działanie dzieci o charakterze interpretacyjnym. Przeprowadzenie tej części badań uniemożliwił obecny nadzwyczajny stan rzeczywistości szkolnej i przejście szkół w tryb pracy zdalnej.

Głównym celem badawczym stała się identyfikacja nadawania znaczeń przestrzeni baśni przez dorosłych użytkowników języka. Badania, przeprowadzone między 12 a 22 marca 2020 r., oparłam na założeniach paradygmatu jakościowego: wywiady z dorosłymi użytkownikami języka (57 studentami pedagogiki - edukacji wczesnoszkolnej i wychowania przedszkolnego) miały charakter eksploracyjny i zmierzały do poznania i opisu zachodzących zależności, zjawisk i zachowań (Jemielniak (red.) 2019), zogniskowanych wokół tekstów baśni tradycyjnych i nowoczesnych. Podział przyjmuję za Violettą Wróblewską (2003), według której baśnie tradycyjne są tekstowymi adaptacjami budowanymi zgodnie z założeniami ludowej bajki magicznej. Baśnie nowoczesne to utwory oparte na autorskich pomysłach pisarza (Wróblewska 2003: 20).

Pierwszym etapem badań było uruchomienie myślenia narracyjnego wokół utworów baśniowych. Zadanie sformułowałam w sposób jak najbardziej ogólny, by utworzyć jak najszerszy horyzont ujawnienia się studenckiej wiedzy osobistej (personal knowledge). Uaktywnienie tego typu wiedzy, w której intuicja, doświadczenia, stany emocjonalne profilują rozumienie wszelkich zagadnień (i nastawienie do nich) - również edukacyjnych - w odniesieniu do przyszłych nauczycieli wydaje się szczególnie ważne. W przyszłości może się bowiem wiązać z budowaniem zrytualizowanej praktyki czy nawet ze skracaniem czasu przeznaczonego na realizację danego zagadnienia (Kalinowska 2010). Ten stopień procesu badawczego miał skierować myślenie studentów w stronę baśni jako tekstów o potencjale edukacyjnym, a jednocześnie ujawnić, czy przestrzeń, wędrówka zostaną potraktowane jako elementy wyjściowe do konstruowania aktywności proponowanych dzieciom. Drugi etap stanowiło wyzwolenie refleksji w oparciu o przestrzeń baśni (miejsce, drogę, wędrówkę), która miała się stać ważnym elementem, a jednocześnie punktem wyjścia dla działań (pytań, które można zadać uczniom, projektowania aktywności oraz celów zajęć). Zarówno w pierwszym, jak i drugim etapie badania studentom pozostawiłam dowolność w zakresie wyboru baśni. Przygotowane przez nich wypowiedzi traktowałam zgodnie z następującymi założeniami: „1) mówienie i pisanie to nie tylko sposoby komunikowania się z innymi ludźmi, ale też określone zachowania społeczne, 2) treść przekazu stanowi istotne świadectwo tego, co jego autor myśli, 
o czym jest przekonany, co uznaje za dobre, a co za złe, co chciałby osiągnąć, a czego uniknąć, 3) dokonanie analizy materiału językowego pozwala wnioskować o niejęzykowych zjawiskach społecznych" (Sołoma 2002: 96-97). Przygotowane przez badanych wypowiedzi w formie tekstowej stały się punktem wyjścia do trzeciego etapu badania, który polegał na przeprowadzeniu wywiadu nieskategoryzowanego na temat przestrzeni baśni. Znaczna elastyczność tej formy umożliwiła mi poruszanie nieprzewidzianych kwestii (Sztumski 1999: 131-132), dzięki czemu ujawniły się motywacje studentów, dotyczące proponowanych celów oraz aktywności dzieci i nauczyciela.

\section{Przestrzeń baśni - przestrzenią działania}

Przestrzeń jako pole działania bohaterów baśni rozpatrywana jest przez badaczy folkloru, literatury, antropologii i psychologii. Bogactwo badań w tym zakresie przynosi kolejne odczytania, dowodzące, że choć istnieją między nimi pewne pęknięcia, to niektóre wykazują niebywałą „łączliwość”. To zjawisko zauważyła m.in. Anna Wasilewska (2012: 55-76, 2015: 239-252), traktując - wyodrębnione przez Władimira Proppa - funkcje bajki magicznej jako obrazy symboli i archetypów psychologii głębi.

Miejsca, ich usytuowanie i dziejące się w nich wydarzenia nie pozostają bez znaczenia również w baśniach ,prze-pisanych”. Baśń bowiem, analizowana z punktu widzenia historyczno-socjologicznego, stanowi reprezentację pewnych idei i relacji społecznych funkcjonujących w rzeczywistości, w której jest opowiadana, jak również „w pełni świadomie bywa przekształcana tak, by podać w wątpliwość lub wręcz skompromitować daną ideę (czy też - szerzej - dany kontekst społeczno-kulturowy), a na jej miejsce zaproponować inną, konkurencyjną, z różnych powodów dotąd niedostrzeganą lub ignorowaną" (Kostecka 2016: 24). Las zatem rozumiany jako symbol zdemonizowanych męskich popędów może się stać przestrzenią oswojoną dla bohaterki postmodernistycznej baśni Angeli Carter, która ostatecznie wybiera rolę towarzyszki wilków (Slany 2016: 284). W odniesieniu do edukacji literackiej w szkole podstawowej, mogącej przełamywać uprzedzenia związane z problemem płci społeczno-kulturowej, Karolina Kwak (2019: 238), przywołując w swojej rozprawie na temat schematów rodzajowych tekst Sławomira Shutego Kopciuszek idzie na wojnę, czyli historia kotem się toczy, zwraca uwagę, że bunt bohaterki, będący zapowiedzią nowego porządku, dokonuje się na symbolicznym szczycie góry.

W artykule przywołuję wybrane interpretacje, stanowiące punkt wyjścia do namysłu nad symboliką przestrzeni i możliwościami jej odczytań, otwierającymi możliwość dalszej interpretacji projektowanych przez kandydatów na nauczycieli aktywności, konstruowanych w oparciu o tradycyjne i nowoczesne baśnie literackie, wyraźnie obecne w podręcznikach szkolnych i listach lektur dla klas I-III.

Dzieło sztuki literackiej samo w sobie można rozpatrywać jako przestrzeń, która za pomocą swej skończoności oddaje nieskończoność świata zewnętrznego (Łotman 1976: 213). Scenerie obecne w opowieści tworzą, mającą symboliczny charakter, „mapę” świata tekstualnego - przestrzeń mitopoetycką. Przybliża ona wyobrażenia dotyczące archaicz- 
nego modelu świata (Toporow 2003: 209). Przestrzeń literacka nie jest zatem tożsama z fizyczną (np. geograficzną), chociaż nie może się od niej zupełnie wyodrębnić, jest modelem świata konkretnego autora (Łotman 1977). W kontekście baśniowych historii to świat pamięci i pragnień ludzkości - narracje te nie mogłyby bowiem powstać, gdyby nie okoliczności, którym towarzyszyły swoiste predyspozycje oraz potrzeby intelektualne i emocjonalne ludzi. Tę myśl można by dopełnić o uniwersalne potrzeby, wyrażone w symbolach - baśń bowiem jest nośnikiem wyobraźni symbolicznej. To zawarte w niej znaki mają moc przyciągania uwagi, emocjonalnego poruszania i pełnego angażowania odbiorcy. Obcowanie z nimi umożliwia inicjację w świat kultury (Ługowska 2006; Baluch 2016). Analiza symboliczna w pewien sposób usuwa zatem miejsca niezrozumienia, dzięki czemu można ustawić rusztowania interpretacyjne w baśniowym lesie symboli (Vaz da Silva 2015: 113).

Baśnie wykorzystują ruch między dosłownym znaczeniem a wyrażeniem przenośnym. Przejściu z realistycznego środowiska, otwierającego historię, do cudownego świata właściwej opowieści towarzyszy odpowiednie przejście od przenośnego znaczenia słów do rzeczy, które te słowa oznaczają. W baśniach metaforyczny wymiar języka nabiera dosłownego znaczenia. Stąd też się bierze wizualna moc baśni (Tatar 2015: 1) - ich pomysły stają się materią (Tatar 1987: 79-82), którą odbiorca powinien odczytać w sposób symboliczny. Budowanie przez przestrzeń charakterystycznych układów znaczeniowych (Łotman 1977) czy konkretnie: uznanie relacji przestrzennych za metaforycznie wyrażające zależności nie-przestrzenne (Burzyńska, Markowski 2009: 249) otwiera drogę do pedagogicznego spojrzenia na przestrzenie baśni. Oto bowiem zależności ułożenia względem siebie rzeczy w świecie, porządku ich przemierzania stają się mapą: potrzeb, wyzwań, trudów, nadziei, dobra i zła. Owa mapa będzie istniała w nieco innym wymiarze dla tradycyjnych i nowoczesnych baśni literackich.

Zrozumienie charakteru przestrzeni tradycyjnej baśni wymaga uznania za prymarny faktu, że to, co umożliwia wniesienie pewnego porządku do sposobu pojmowania świata, polega na ujmowaniu wszystkiego w pary przeciwieństw (Bettelheim 1985: 150). Wiąże się to z zasadniczą funkcją naszego umysłu, jaką jest „tworzenie świata” (Bruner 1990: 3). Bajki magiczne same w sobie są zatem dowodem na naturalną skłonność człowieka do porządkowania świata. Ich przestrzeń czy też - rzeczywistość intencjonalna - jest jednym z przejawów stereotypowości tradycyjnej baśni (Ługowska 1981). Nadrzędną zasadą organizacji tekstu staje się budowanie owej rzeczywistości w sposób umożliwiający tryumf wartości pozytywnych nad negatywnymi (Niebrzegowska-Bartmińska 2002: 89). Przestrzeń w baśniach tradycyjnych zbudowana jest wokół osi wyznaczanej przez dwa światy: realny i magiczny, w którym panują zupełnie inne prawa (Propp 2000: 115). Podróż bohatera rozpoczyna się zawsze w bliskiej przestrzeni domu i w toku całej historii przybiera schemat dom-świat lub dom-świat-dom (Niebrzegowska-Bartmińska 2002: 94). Charakterystyczne jest przy tym, że to w sferze oddalonej najczęściej dochodzi do wszelkich zjawisk naznaczonych cudownością. Droga bohatera wiedzie przez niebezpieczne, pełne wyzwań obszary. Najczęściej występującym miejscem staje się las/bór (Jaś i Małgosia, 
Królewna Śnieżka, Czerwony Kapturek), choć „bywalcy bajki” wędrują też przez góry, morza i pustynie (Malinowski 1953: 136).

Taki podział świata wpisuje się w kategorie orbis interior i orbis exterior. Przestrzeń bliska może być naznaczona sytuacją braku i nieszczęścia, lecz po przebyciu drogi przez bohatera odmienia się - staje się bezpieczna, uczłowieczona, jak w Jasiu i Małgosi, gdzie opis domu jest klamrą kompozycyjną i zamyka w sobie tragizm - na początku i szczęście - na końcu utworu. Zdarza się, że protagonista nie powraca do domu, a pozostaje w ,innym królestwie”, które wyzwolił spod działania zła. Odzwierciedla to ludzką chęć zdobywania i oswajania nowych przestrzeni oraz realizacji marzenia, by to, co nieznane, stało się bliskie i bezpieczne (Grochowski 1999: 16).

Przywołana wcześniej teza o porządkowaniu świata przez opowieści baśniowe ujawnia się także w rozważaniach semiotyków. Jak uważa Łotman, naturalna skłonność człowieka do kategoryzowania przejawia się przez ustanawianie opozycji binarnych: „,semiotyka prawej/lewej strony ma tak samo uniwersalny dla wszystkich kultur charakter, jak i przeciwstawienie góra/dól" (2008: 207). Opozycyjny wymiar przestrzeni tradycyjnej baśni wyraża się zatem w usytuowaniu względem siebie poszczególnych lokacji, który uwzględnia pionowy i poziomy podział świata i pojawiające się w nim granice. Przeciwstawne kategorie: góra-dół, lewo-prawo stają się nośnikami aksjologicznymi - wokół nich ogniskuje się to, co związane $\mathrm{z}$ dobrem i ze złem.

Ostatnim elementem „mapy” świata tradycyjnej baśni, który wydaje się szczególnie ważny z pedagogicznego punktu widzenia, jest fakt, że podróż przez wyraźnie opozycyjną przestrzeń przynosi czytelnikowi pociechę i wiarę we własne siły. Piotr Matywiecki, pisząc o baśni jako marzeniu o sensie literatury, przywołuje myśl Eliasa Cantiego: „Można by sobie życzyć, żeby był jeszcze jeden świat, całkowicie nietknięty; (...) nigdzie nie oczekiwany; a jednak zrozumiały, gdy nagle przychodzi nam z pomocą" (Canti, za: Matywiecki 2005: 34). Taką konstrukcją jest $\mathrm{w}$ istocie bajka magiczna, której perypetie toczą się wszędzie i nigdzie, jednocześnie ukazująca nadzieję w zrealizowaniu się jej praw w prawdziwym życiu - dobro zwycięży, a zło zostanie ukarane.

Innym światem jest ten skonstruowany przez Hansa Christiana Andersena: daleko mu do ideału, nie jest taki, jaki powinien być, by nieść nadzieję na oswojenie przestrzeni. Jego opowieści są w istocie zaprzeczeniem skryptu akcji, który Joanna Ślósarska (2018: 35) scharakteryzowała jako zamykający wewnętrzną podróż bohaterów toposem korzystnego usytuowania się w środowisku. Nawet jeśli postaciom uda się dotrzeć na powrót do orbis interior - szeroki świat nadal pozostaje w zagrożeniu - zło nie zostaje z niego usunięte. W Królowej Śniegu udaje się dzięki miłości usunąć zło z serca Kaya, ale w świecie pozostają biliony okruchów i każde dziecko może zostać uwiedzione przez królową ,reprezentującą demoniczną moc budzenia zachwytu i grozy, umożliwiającą doznanie niezwykłego piękna bez uczucia miłości do kogokolwiek i czegokolwiek" (Ślósarska 1997: 29). Cierpień i smutku nie da się ze świata wymazać, a ich źródłem często są ludzie - jak w Stokrotce czy Dziewczynce z zapałkami. Ta baśń w szczególności ukazuje odbiorcom istnienie antywzorów, realnych zagrożeń i dramatów. Przekazuje prawdę, że przestrzeń domu nie 
zawsze zostaje oswojona. Dla zrozumienia tych kwestii ważne jest odtworzenie położenia i wyglądu domu dziewczynki oraz relacji między tym, co powinno dawać wnętrze i czym grozi świat zewnętrzny (Wiśniewska-Kin 2010: 77, 2013: 257-263). Istotną różnicą między przestrzenią baśni tradycyjnej i nowoczesnej staje się tutaj jednak status zaświatów, do których - ze względu na chrześcijański wymiar opowieści - pragną trafić bohaterowie Andersena, by zakończyć pełną trudu ziemską wędrówkę i połączyć się z Bogiem.

W baśniach Duńczyka, których bohaterami są przedmioty (ołowiany żołnierzyk, imbryk, szyjka od butelki) lub rośliny (stokrotka, len, choinka), istnieją dwie płaszczyzny przeżywania. Życie ludzkie i życie przedmiotów oddzielone jest zasłoną, której człowieczy bohaterowie nie przekraczają, brak im bowiem wyobraźni. „Nie każdy przedmiot budzi marzenie poetyckie. Z chwilą jednak gdy poeta wybrał jakiś przedmiot, sam ten przedmiot zmienia swój status. Awansuje do świata poezji (...). To, co staje się przedmiotem celebracji, zyskuje nową godność istnienia" (Bachelard 1975: 394). Ludzie w tych tekstach nie przypisują roślinom i przedmiotom statusu duchowego - dzieci nie żałują umierającej stokrotki, imbryk zaś zostaje zbity przez „,niezdarną rękę”. Za to dziecko jako czytelnik postawiony jest na piedestale: jemu jest dana możliwość zajrzenia za zasłonę znaczeń. Sprawdzianem wrażliwości jest to, czy marzy o tym, by tę zasłonę zerwać i zapobiec niesprawiedliwościom i okrucieństwu świata, czy chce miejsca pozbawione uczuć nasycić empatią (Brzydkie kaczątko, Calineczka) (Ogłoza 2014: 256).

Różnice pod względem ładunku optymizmu między baśniami tradycyjnymi a utworami Andersena nie wykluczają w tych drugich możliwości organizacji metaforycznej wędrówki ku wartościom na linii wertykalnej i horyzontalnej. Przykładem ruchu ku górze jest droga, którą przemierza syrena, tej wędrówce wertykalnej można przypisać dojrzewanie i wzrastanie duchowe bohaterki. Wypływa ona z głębin morza, przemierza ziemię, by w końcu unosić się nad jej powierzchnią, zbliżając się do słońca, nasyconego znaczeniem życiodajności i najwyższego szczęścia. „W tych różnych miejscach przestrzeni świata przedstawionego syrenka rozwija wieloaspektowo swoją osobowość - w ciemności głębin morza przygotowuje się do poznania świata, przyswaja o nim wiedzę z cudzych opowieści (babki i sióstr). Na powierzchni, czyli na ziemi, doświadcza miłości (...). W powietrzu natomiast ma miejsce rozwój duchowości religijnej” (Ogłoza 2014: 63).

Droga bohatera baśni i charakter miejsc, które przemierza, najpełniej krystalizują się w cytacie J.R.R. Tolkiena: „Magia Królestwa Czarów nie jest celem samym w sobie, jej moc przejawia się w działaniu; między innymi w zaspokajaniu pierwotnych ludzkich potrzeb. Jedną z takich potrzeb jest pragnienie zbadania głębin czasu i przestrzeni” (1994: 20).

Przestrzeń baśni ujawnia się zatem nie tylko jako zbiór immanentnych miejsc. Przywołany zostaje ich związek z czasem (możliwy poprzez wprowadzenie kategorii czasoprzestrzeni), a nade wszystko z działaniem, które faktycznie jawi się trojako: 1) jako oddziaływanie miejsc (posiadających określone cechy, „wyposażonych” w występujące w nich postaci, zjawiska i przedmioty); 2) jako działanie bohatera w owych miejscach - domach, zamkach, lasach, w podziemiach i na najwyższych górach, daleko i blisko; 3) jako działanie odbiorcy tekstu, który wraz z protagonistą przemierza drogę baśni; ta wspólna podróż 
nakierowana jest na poznanie dzieła (w którym to poznaniu uprawomocnia się również element intuicyjny), a jego osiągnięcie realizuje się ostatecznie w kompensacyjnej funkcji literatury.

\section{Dyskurs kandydatów na nauczycieli - przykłady ujawniania przestrzeni baśni}

\section{Przestrzeń niebezpieczeństw - przestrzeniq zabawy}

Nie chciałam, by baśń kojarzyła się dzieciom z czymś przykrym, a to, co dzieje się w chatce Baby Jagi, może budzić grozę.

Ta wypowiedź ogniskuje wokół siebie podobne uwagi, będące podstawą do projektowania aktywności o charakterze zabawy, których przykłady stanowią: wyliczanki i piosenki (również ośmieszające, ujmujące potęgi baśniowym przeciwnikom - ujawniły się tutaj także znane utwory, które ze względu na pewien wspólny motyw zostały „przypisane” do baśni - np. Zima zła Marii Konopnickiej jako propozycja przy działaniach skonstruowanych wokół Królowej Śniegu), zabawy ruchowe i sprawnościowe (raz, dwa, trzy, Baba Jaga patrzy; aktywności, w których dzieci jako wilki polują na czerwone kapturki - przy czym bycie wilkiem staje się niejako nagrodą dla uczestnika), budowanie z klocków zamkowych wież, nieograniczona ekspresja ruchowa przy utworach muzycznych w tonacji majorowej. Owa nieograniczona ekspresja jawi się tutaj jako wielokrotnie przywoływane znamienne hasło, bowiem według badanych podczas improwizacji tańcem („tańczymy wokół chatki Baby Jagi”) lub działań plastycznych (,wyklejamy zimowy pałac”):

każde dziecko może przedstawić to, co widzi w tekście, i w dodatku wyrazić się twórczo, a każda interpretacja rysunkowa może być zupełnie inna, każda może być inna i dobra.

Wypowiedzi ujmujące przestrzeń baśni jako punkt wyjścia do wymienionych aktywności definitywnie oddalają aktywność odbiorców od tekstu literackiego.

\section{Tekst baśniowy - „dziecięca szata” przestrzeni dydaktycznej}

Traktowanie przestrzeni baśniowej jako tożsamej z naturalnym otoczeniem przyrodniczym sprawia, że nasycona zostaje elementami nieobecnymi w tekście, pożądanymi natomiast z „realnego” punktu widzenia. Bywa, że scenę „wejścia” do przestrzeni opowieści odbiorcy mają odegrać za pomocą atrybutu obecnego („każde z dzieci może dostać koszyczek, żeby być gotowym na wyprawę do babci”) bądź nieobecnego w tekście (,dzieci wsiadają do łodzi podwodnej i zakładają okulary pływackie, żeby zejść na dno morza, gdzie mieszkała syrenka)". Badani proponowali kreowanie miejsc opowieści poprzez uprzednie dekorowanie sal lekcyjnych: 
Nauczyciel może wcześniej przygotować tło lasu, styropianowe grzyby. Zapytać dzieci, które z nich mógł zebrać Czerwony Kapturek.

Według badanych miejsca opisane w baśni:

Można przypisać temu, co jest wokół nas, co prawda nie żyjemy w świecie czarów, ale można porozmawiać z dziećmi na przykład o lesie. Co można tam robić, czego nie, co zabrać na leśną wyprawę, jak się zachować w lesie w czasie burzy.

Formułowano również propozycje odczytywania utworów, w których występował motyw lasu podczas biwaku, wycieczki, żeby „poczuć się jak bohaterowie baśni, doświadczyć piękna przyrody". Następuje zatem próba postawienia znaku równości między lasem baśni (przestrzenią obcą, pełną dramatycznych przygód i niebezpieczeństw - często miejscem, w którym mieszka zło) a lasem realnym, w którym uczestnicy wycieczki mają się znaleźć w zupełnie innych okolicznościach:

Las nie jest aż tak straszny, jak go przedstawiają różne baśnie i bajki, jeśli postępujemy w nim odpowiedzialnie i nie zbaczamy z wyznaczonych szlaków i ścieżek - wtedy las jest przyjazny.

Szczególną rolę w promieniowaniu baśni na konkretne obszary wczesnej edukacji zajęła edukacja społeczna. Wielokrotnie pojawiająca się wśród badanych fraza „baśń uspołecznia” ujawnia nie tylko sposób widzenia baśniowej przestrzeni i jej bohaterów, ale też kreowany w wypowiedziach charakter owego uspołeczniania. Jeżeli bowiem baśń „niesie przesłanie, morał czy coś w rodzaju nauczki” (zakładając, że nauczka jest przestrogą związaną z doznanym przykrym doświadczeniem), uwaga odbiorców zostaje skierowana W stronę postaci z kręgu antagonistów, które faktycznie zostały ukarane (np. siostry Kopciuszka) lub na pojedyncze epizody z drogi bohatera.

Czerwony Kapturek postąpił bezmyślnie, że rozmawiał z kimś obcym i to daleko od domu, Jaś i Małgosia nie powinni oddalać się od dorosłych.

Co jednak z faktem, że oddalenie nastąpiło z powodu uzasadnionego braku, jakiego doznawały dzieci na początku opowieści, a także umożliwiło skonstruowanie fabularnej linii napięć, pokonanie zła i powrót do przestrzeni bezpiecznej?

Projektowana aktywność uczniów implikuje również zmiany w usytuowaniu elementów przestrzeni. Wilk pojawia się „,na końcu lasu” (w którym dzieci miały uprzednio wykonywać zadania - matematyczne, plastyczne itd.), podczas gdy w opowieści dziewczynka spotyka go dokładnie w połowie drogi. Przesunięcie postaci wilka zaburza jego „promieniowanie” na model świata, usuwając zagrożenie z centrum przestrzeni lasu. 
Wskażcie, które wyrazy należą do tej samej rodziny wyrazów co wyraz „las”, Które dary lasu są jadalne, a które niejadalne? Policzcie, ile rybek spotkała syrena po drodze do domu, Wybierzcie zasady savoir-vivre'u, których Kopciuszek powinien przestrzegać w zamku.

Takie formułowanie zadań ma według badanych uatrakcyjnić działanie w obszarze poszczególnych edukacji:

dzieciom przyjemniej będzie się pracowało, kiedy wszystkie działania będą miały odniesienia do baśni, jeśli akurat ją omawiamy.

Takie wypowiedzi potwierdzają również konstrukcje zagadnień baśniowych w pakietach edukacyjnych.

\section{Przestrzeń gry znaczeń}

Bywa, że przestrzeń baśni zmienia swe oblicze - w sposób głębszy niż w przypadku dyskursu pierwszego, następuje bowiem pogłębiona przez badanych zmiana charakteru antagonistów. Ze złem można negocjować, pozwoli nam wtedy na opuszczenie niebezpiecznych miejsc:

Jestem bardzo głodny, a wy tak smacznie wyglądacie! Widać, będę mieć smaczny obiad. Jednak dam wam jedną szansę. Nie połknę was, pod warunkiem że dostanę od was bukiet kwiatków. Ale to nie taki prosty bukiet. Mam swoje ulubione kolory i z nich musi być bukiecik! Zróbcie to szybko, zanim zmienię zdanie!

Już samo negocjowanie przełamuje binarną opozycję aksjologiczną, wilk w dodatku okazuje się prawdomówny, a fakt, że wcześniej „,uwiódł” bohaterkę słowami niczym czarnoksięskim zaklęciem, przestaje się liczyć:

Zrobiliście takie śliczne bukiety! Dotrzymuję słowa i dzisiaj was nie połknę. Jednak dzisiaj nie jestem taki okrutny jak zwykle i możecie wziąć te bukieciki do babuni.

W przykładzie tym las stał się miejscem zadań dydaktycznych i zabaw, a wyjście z niego zagrodził wilk, który groźny po prostu bywa (może jedynie dla dzieci, które nie wykonają prawidłowo poleceń). Krok naprzód stanowi działanie, w którym ,zadaniem jest stworzenie domku - pałacu dla Baby Jagi, ale dla Baby Jagi, która nie je dzieci i nie robi złych rzeczy, tylko jest dobrą i kochaną babcią". Podejmowane takich interpretacji ma według badanych:

„odczarować” złych bohaterów i złe miejsca. Należy pokazać, że złe osoby też mogą przejść przemianę i można im pomóc wrócić na dobrą drogę. Tak dzieje się także w życiu codziennym. 
W wypowiedziach podkreślano, że takie działania podyktowane są empatią i chęcią niesienia pomocy: „każdemu trzeba dać szansę”.

Na zmianę charakteru przestrzeni i postaci może rzutować nie tylko humanistyczno-adaptacyjne podejście badanych, ale też nawarstwienie znaczeń, które uprzednio trafiły do nich jako odbiorców kultury audiowizualnej: „Królowa Śniegu nie musiała być przecież zła”. Ujawnia się tutaj - opisywana we wstępie - gra znaczeń, występująca również w disnejowskiej animacji Frozen (choć główna bohaterka Elza, jak przyznali twórcy, początkowo miała być prawdziwą antagonistką, do której udaje się Anna, by prosić o zamrożenie swojego złamanego serca).

\section{Potencjalna przestrzeń symboliczna}

W wypowiedziach badanych przestrzeń w rozumieniu symbolicznym nie ujawniła się w pierwszych konstruowanych wypowiedziach. Stało się to, jak twierdzili respondenci, „po namyśle” i dotyczyło raczej utworów Andersena.

Po zastanowieniu widzimy przecież, że przygoda Calineczki zaczyna się w świecie ludzi, istot większych od niej. Mimo iż kobieta bardzo ją kochała i pragnęła mieć dziecko, nie było to środowisko, w którym czuła się swobodnie. Następnie akcja toczy się w świecie zwierząt, dzięki którym dowiadywała się, iż to też nie jest ten ,świat” (kret nie był jej wymarzonym mężem). Dzięki przygodom poznawała siebie, swoją dobroć i umiejętności. Na końcu baśni odnajduje swoje miejsce wśród małych istot, w którym czuje się dobrze, ponieważ są oni podobni do niej.

W istocie ujawnia się tutaj to, co obecne jest w Brzydkim kaczątku i wielu innych baśniach Duńczyka:

Gdyby Calineczka nie przebyła tej drogi - nigdy nie mogłaby być szczęśliwa, nie urosłaby przecież, nie stałaby się człowiekiem, byłaby samotna.

Podróż, choć bywa, że zostajemy ku niej popchnięci wbrew naszej woli, pozwala znaleźć swoje miejsce w życiu.

Ujawniło się również symboliczne spojrzenie na przestrzeń wędrówki, a także ułożenia względem siebie przedmiotów:

Syrena płynęła ku górze, bo tam był cel, do którego zmierzała, jej największe pragnienie.

Materace oddzielały królewnę od ziarna, pomimo że była wysoko ponad nim, nadal była „wrażliwa” na jego działanie.

To dowód na delikatność prawdziwej księżniczki, ale może być także punktem wyjścia do interpretacji aksjologicznej - być królem/królową w życiu oznacza być wrażliwym na 
zło: nawet jeśli jest daleko od nas, przesłaniają je sprawy codzienności, to nadal je czujemy, jesteśmy ,posiniaczeni” jego oddziaływaniem.

\section{Konkluzje}

Postrzeganie przestrzeni baśni przez kandydatów na nauczycieli, ujawnione w opisanych dyskursach, dowodzi, że dzieło literackie - baśń z rzadka staje się punktem wyjścia do rozważań na temat jej struktury, symbolicznych elementów czy aksjologii.

Znamiennym wątkiem, który z pewnością zostanie poddany dalszym analizom, jest niechęć do symbolicznego spojrzenia na baśniowe zło. To dzięki „realistycznemu” postrzeganiu antagonistów przemienia się ono w dobro. Takie odniesienia istnieją już w obcojęzycznych wydawnictwach dla dzieci - np. w serii Fairytale Friends, gdzie w części Snow White, Star Striker pojawiają się Griselda - troskliwa staruszka z koszyczkiem jabłek, będąca odzwierciedleniem (w oryginale okrutnej) macochy, i Rumpelstiltskin, który zostaje trenerem drużyny piłkarskiej i przedstawia czytelnikom, na czym polega umiejętność współdziałania. Otwiera to jednak drogę do sytuacji, w której - w analogiczny sposób - dobro może przemienić się w zło.

Proponowane aktywności dowodzą wpływu współczesnych filmowych adaptacji, odmiennych od tekstów, na których motywach są oparte. W Krainie Lodu to nie „królowa śniegu", lecz książę Hans stanowi źródło zła, a Mała syrenka, ostatecznie otrzymawszy nogi od swojego ojca, bierze ślub z księciem Erykiem. W wypadku tej drugiej baśni pojawiła się znamienna wypowiedź: „Nie zdawałam sobie sprawy, że istnieje inna wersja zakończenia niż ta filmowa”. Francisco Vaz da Silva (2016), prowadząc zajęcia ze studentami antropologii społecznej, proponuje uczenie się symbolizmu baśni poprzez analizę ich konkretnych wersji - np. trzech wersji Czerwonego Kapturka, niosących szereg różnych znaczeń. Ten trop myślenia powinien w istocie stać się inspiracją do dyskusji i refleksji podejmowanej także ze studentami pedagogiki - na płaszczyźnie aksjologicznej tekstów. Wczesna edukacja literacka, która powinna się opierać na sile sprawczej przeżycia estetycznego, wymaga dostrzeżenia cech konkretnego utworu i wniknięcia w jego artystyczną rzeczywistość. Dzięki temu można uniknąć dysonansu powstającego np. w wyniku naddania przestrzeni lasu konotacji miejsca bezpiecznego i pełnego radości w baśniowych adaptacjach braci Grimm.

Motywy baśniowe zapewne są i będą nieustannie przetwarzane w różnych dziełach kultury, a drogę do ich rozszyfrowania można uzyskać jedynie przez kształtowanie odbiorczej wrażliwości kompetencji czytelniczych czy szerzej - kompetencji kulturowych. Konieczne zatem wydają się działania interwencyjne w zakresie przeciwstawiania się edukacji polonistycznej fast life i infantylizowaniu dziecięcych odbiorców. 


\section{Literatura}

Bachelard G. (1975), Cogito marzyciela. W: tegoż, Wyobraźnia poetycka. Wybór pism. Warszawa, PIW.

Baluch A. (2016), Co warto wiedzieć o literaturze dla dzieci i młodzieży. W: U. Chęcińska (red.), Dziecko i baśnie świata w kontekście wczesnej edukacji. Szczecin, Wydawnictwo Naukowe Uniwersytetu Szczecińskiego.

Bettelheim B. (1985), Cudowne i pożyteczne. O znaczeniach $i$ wartościach baśni. Warszawa, PIW. Bruner J. (1990), Życie jako narracja. „Kwartalnik Pedagogiczny”, 2.

Burzyńska A., Markowski M. (2009), Teorie literatury XX wieku. Kraków, Wydawnictwo Znak.

Grochowski P. (1999), Przestrzeń i świat jako elementy baśniowej wizji świata, „Literatura Ludowa", 1.

Janus-Sitarz A. (2013), Wplyw uniwersyteckiej dydaktyki literatury na aksjologiczne aspekty szkolnej edukacji polonistycznej. W: M. Marzec-Jóźwicka (red.), Wartości i wartościowanie w edukacji humanistycznej. Lublin, Towarzystwo Naukowe KUL.

Jemielniak D. (red.) (2012), Badania jakościowe. T. 2: Metody i narzędzia. Warszawa, Wydawnictwo Naukowe PWN.

Kalinowska A. (2010), Matematyczne zadania problemowe w klasach początkowych-między wiedza osobista a jej formalizacją. Kraków, Oficyna Wydawnicza „Impuls”.

Klus-Stańska D. (2007), Między wiedza a władza. Dziecięce uczenie się w dyskursach pedagogicznych. „Problemy Wczesnej Edukacji”, 5-6.

Kostecka W. (2016), Baśniowe herstory. Postmodernistyczne strategie reinterpretacyjne Angeli Carter, Tanith Lee i Emmy Donoghue, „Creatio Fantastica”, 2(53).

Kwak K. (2019), Czy Kopciuszek musi być dziewczyną? Kraków, Universitas.

Leszczyński G. (2006), Baśń: rytuat przejścia (,,rite de passage”). W: G. Leszczyński (red.), Kulturowe konteksty baśni. T. 2. Poznań, Centrum Sztuki Dziecka w Poznaniu.

Łotman J. (1976), Problem przestrzeni artystycznej. „Pamiętnik Literacki”, 67.

Łotman J. (1977), Zagadnienia przestrzeni artystycznej w prozie Gogola. W: E. Janus, M.R. Mayenowa (wybór, oprac.), Semiotyka kultury. Warszawa, PIW.

Łotman J. (2008), Pojęcie granicy. W: tegoż, Uniwersum umystu. Semiotyczna teoria kultury. Gdańsk, Wydawnictwo Uniwersytetu Gdańskiego.

Ługowska J. (1981), Ludowa bajka magiczna jako tworzywo literatury. Wrocław, Zakład Narodowy im. Ossolińskich.

Ługowska J. (2006), Baśń jako wprowadzenie do myślenia aksjologicznego. W: G. Leszczyński (red.), Kulturowe konteksty baśni. T. 2. Poznań, Centrum Sztuki Dziecka w Poznaniu.

Malinowski L. (1953), Powieści ludu na Śląsku. Kraków, Wydawnictwo Literackie.

Matywiecki P. (2005), Baśń jako marzenie o sensie literatury (Pomysty do dalszego rozwinięcia). W: G. Leszczyński (red.), Kulturowe konteksty baśni. T. 1: Rozigrana córa mitu. Poznań, Centrum Sztuki Dziecka w Poznaniu.

Niebrzegowska-Bartmińska S. (2002), Porządek tekstu bajki jako odwzorowanie świata. W: A. Mianecki, V. Wróblewska (red.), Genologia literatury ludowej. Toruń, Wydawnictwo Uniwersytetu Mikołaja Kopernika.

Ogłoza E. (2014), Wokół opowieści Hansa Christiana Andersena. O radości czytania. Katowice, Wydawnictwo Uniwersytetu Śląskiego.

Propp W. (2000), Nie tylko bajka. Warszawa, Wydawnictwo Naukowe PWN. 
Slany K. (2016), ,Orbis exterior” w baśni magicznej i jego symbolika w „Oblubienicy Tygrysa” $i$,,Towarzystwie wilków” Angeli Carter. W: W. Kostecka, M. Skowera (red.), Geografia krain zmyślonych. Wokót kategorii miejsca i przestrzeni w literaturze dziecięcej, młodzieżowej i fantastycznej. Warszawa, Wydawnictwo SBP.

Sołoma L. (2002), Metody i techniki badań socjologicznych. Olsztyn, Uniwersytet Warmińsko-Mazurski.

Sztumski J. (1999), Wstęp do metod i technik badań społecznych. Katowice, Wydawnictwo Naukowe „Śląsk”.

Ślósarska J. (1997), Kreacja przedmiotu w baśniach Hansa Christiana Andersena. W: M. Hempowicz (red.), Andersen - baśń wobec świata. Gdańsk 21-22 kwietnia 1995 roku. Materiaty z sesji literackiej w 190. rocznicę urodzin Hansa Christiana Andersena. Gdańsk, Nadbałtyckie Centrum Kultury.

Ślósarska J. (2018), Skrypty losu. Łódź, Wydawnictwo Primum Verbum.

Tatar M. (1987), The Hard Facts of the Grimms' Fairy Tales. Princeton, NJ, Princeton University Press.

Tatar M. (2015), Introduction. W: tejże, The Cambridge Companion to Fairy Tales. Cambridge, University Press.

Tolkien J.R.R. (1994), O baśniach. W: tegoż, Drzewo i liść oraz Mythopoeia. Poznań, Wydawnictwo Zysk i S-ka.

Toporow W. (2003), Przestrzeń i rzecz. Kraków, Universitas.

Vaz da Silva F. (2015), Fairy-tale symbolism. W: M. Tatar (ed.), The Cambridge Companion to Fairy Tales. Cambridge, University Press.

Vaz da Silva F. (2016), Teaching Symbolism in „Little Red Riding Hood”. W: J. Christa, C. Schwabe (ed.), New Approaches to Teaching Folk and Fairy Tales. Utah, State University Press.

Wais J. (2007), Ścieżki baśni. Symboliczne wędrówki do wnętrza duszy. Warszawa, Eneteia.

Wasilewska A. (2012), Fantastyka baśniowa a dziecko - wychowanie czy manipulacja? Gdańsk, Wydawnictwo Uniwersytetu Gdańskiego

Wasilewska A. (2015), Baśniowe przestrzenie - wewnętrzna topografia świata życia człowieka. W: T. Sadoń-Osowiecka (red.), Miejsce, przestrzeń, krajobraz. Edukacyjne znaki. Gdańsk, Wydawnictwo Uniwersytetu Gdańskiego.

Wiśniewska-Kin M. (2010), ,Stan hibernacji” dziecięcych możliwości a ożywczy potencjał metody przekładu intersemiotycznego. „Forum Oświatowe”, 2(43).

Wiśniewska-Kin M. (2013), Dominacja a wyzwolenie. Wczesnoszkolny dyskurs podręcznikowy i dziecięcy. Łódź, Wydawnictwo Uniwersytetu Łódzkiego.

Wróblewska V. (2003), Przemiany gatunkowe polskiej baśni literackiej XIX i XX wieku. Toruń, Wydawnictwo Adam Marszałek.

Wygotski L. (1980), Psychologia sztuki. Kraków, Wydawnictwo Literackie.

Żuchowska W. (1992), Oswajanie ze sztuka słowa. Warszawa, WSiP.

Żuchowska W. (1998), Szansa w metodzie. „Nowa Polszczyzna”, 2(7). 